\title{
“Brutal Kill!" Violent video games as a predictor of aggression
}

\author{
Bruno Gonçalves de Medeiros ${ }^{7}$ \\ Carlos Eduardo Pimentel ${ }^{2}$ \\ Mauricio Miranda Sarmet ${ }^{3}$ \\ Tailson Evangelista Mariano ${ }^{2}$ \\ ${ }^{1}$ Universidade Federal do Rio Grande do Norte \\ ${ }^{2}$ Universidade Federal da Paraíba \\ ${ }^{3}$ Instituto Federal de Educação, Ciência e Tecnologia da Paraíba
}

\begin{abstract}
In recent years, many international studies have investigated the relationship between violent games and violence, aggressiveness and delinquent behavior, but there are scarce studies in Brazil on the subject. The aim of this research was to investigate the relationship between dispositional behavior and antisocial behavior correlated with the playing of violent content video games. A total of 249 high school students participated in the study, of which 154 were women and 95 were men, aged 13-20 years $(\mathrm{M}=15.4$, DP $=1.12)$, who responded the following scales: Big Five Inventory, Buss and Perry Aggression Questionnaire, Antisocial and Criminal Behaviors Questionnaire and a new Scale of Video Games Violence. The regressions performed indicated that the violent games, antisocial behavior, anger and sex were predictors for physical aggression. In conclusion, the study confirms the hypothesis of the General Aggression Model on human aggression in which violent games are associated with aggressive behavior.

Keywords: violence; video games; risk factors; aggression
\end{abstract}

“Brutal Kill!” Videogames Violentos como Preditor da Agressão

\begin{abstract}
Resumo
Nos últimos anos muitos estudos internacionais têm investigado a relação entre jogar jogos violentos e comportamento agressivo e delinquente, mas tem-se verificado uma escassez desses estudos no Brasil. O objetivo da pesquisa foi investigar a relação entre traços disposicionais e comportamentos antissociais com o consumo de videogames violentos. Participaram 249 estudantes do ensino médio, sendo 154 do sexo feminino e 95 do sexo masculino, e idade variando de 13 a 20 anos $(M=15,4 ; D P$ $=1,12$ ), tendo respondido às seguintes escalas: Inventário dos Cinco Grandes Fatores, Questionário de Agressão de Buss e Perry, Questionário de Comportamentos Antissociais e Delitivos e a Escala de Violência nos Videogames. A regressão indicou que jogar videogames violentos, comportamento antissocial, raiva e gênero foram preditores da agressão física. Conclui-se que este estudo corrobora com a hipótese do Modelo Geral da Agressão sobre a agressão humana na qual os jogos violentos estão associados ao comportamento agressivo.

Palavras-chave: violência, videogames, fatores de risco, agressão
\end{abstract}

“Brutal Kill!" Videojuegos violentos como predictores de agresión

\section{Resumen}

En los últimos años muchos estudios internacionales han investigado la relación entre jugar juegos violentos y comportamiento agresivo y delincuente, aunque en Brasil se ha verificado escasez de estos estudios. El objetivo de la presente búsqueda fue investigar la relación entre rasgos disposicionales y comportamientos antisociales con el consumo de videojuegos violentos. Para ello se contó con la participación de 249 estudiantes de Enseñanza Secundaria, siendo 154 de sexo femenino y 95 de sexo masculino, y edades variando de 13 a 20 años $(M=15,4, D P=1,12)$, que respondieron las siguientes escalas: Inventario de los Cinco Grandes Factores, Cuestionario de Agresión de Buss y Perry, Cuestionario de Comportamientos Antisociales y Delictivos y la Escala de Violencia en los Videojuegos. La regresión indicó que jugar videojuegos violentos, comportamiento antisocial, rabia y género fueron predictores de agresión física. Se concluye que este estudio corrobora con la hipótesis del Modelo General de Agresión sobre agresión humana en la cual los juegos violentos están asociados al comportamiento agresivo.

Palabras clave: violencia, videojuegos, factores de riesgo, agresión

\section{Introduction}

The digital gaming industry has become more conspicuous over the past years. From an economic point of view, its growth began in the 1970s with the emergence of the Atari video game company, created by Nollan Busnell and Ted Dabney (Mora-Cantallops \& Sicilia, 2018), and has now surpassed more established industries such as, for example, the cinema (Pinto, Coronel \& Bresolin, 2013). In addition, the inclusion of 
digital video games in the daily lives of the population has a role in the social, cognitive and emotional development of children and young adults who enjoy this kind of entertainment (Ashinoff, 2014; Kühn, Gleich, Lorenz, Lindenberger, \& Gallinat, 2014, Stansbury, Wheeler, \& Buckingham, 2014).

There has been an increasing debate about the consequences of video gaming on people's behavior and attitudes, as it had once occurred with movies and other forms of media. It is noteworthy that researchers have positively associated video gaming with a set of negative influences, such as greater cognitive accessibility to aggressive content (Anderson, Carnagey, Flanagan, Benjamin, Eubanks \& Valentine, 2004), higher propensity for antisocial behavior (DeLisi, Vaughn, Gentile, Anderson \& Shook, 2013; Gentile \& Bushman, 2012; Mariano, 2016), greater occurrence of negative affective states (Anderson \& Dill, 2000), and reduction in prosocial behaviors (Anderson et al., 2010; Bushman \& Huesmann, 2014).

Intense debate has aroused among researchers who argue that this influence does not exist or that it is not relevant, such as Elson and Ferguson (2013), and those who confirm an association, such as Bushman and Heusmann (2014) and Krahé (2014). The probable association becomes more significant when the most successful games display content related to violence or unfavorable social messages, such as God of War and Red Dead Redemption (Gouveia, Mariano, Nascimento, Grangeiro, Medeiros, 2017; Kasumovic, Blake, Dixson, \& Denson, 2015).

When comparing this discussion with others related to the effects of other media on antisocial behavior, exposure to violence in digital games is different due to permanent attention, interactivity and active psychological participation of players, which according to some authors could easily promote more negative effects, such as aggressive thoughts, than other media (Ferreira, Carneiro, Miguéis, Soares, \& Esteves, 2009, Granic, Lobel \& Engels, 2014).

Swing, Gentile and Anderson (2009), following this reasoning, argue that certain characteristics of digital games can potentiate lasting changes in behavior, such as: difficulty level control, allowing greater adjustment to the player's expertise; recurrent application of specific skills, which characterizes a training situation; existence of an active learning process due to the players' engagement; reward systems and immediate feedback; possibility of generalization of specific behaviors in broader contexts.
Therefore, it is still relevant to investigate and further understand the phenomena related to the exposure of youth to violent games (Anderson \& Bushman, 2001; Gee, 2003). To explain and understand the effects of exposure to violent content in entertainment media, we will use the Risk Factor Paradigm that seeks to identify risk factors for delinquent behavior, seeking to design appropriate prevention measures (Farrington, 2000). Exposure to violence has been identified as a risk factor (among several others such as, for example, previous involvement in physical aggression, gender, and hostile attribution bias) (Bushman \& Huesmann, 2006; Anderson et al., 2010). Studies that have included exposure to violence through media as a risk factor for aggressive and antisocial behavior have paved the way for this approach and for expanding knowledge about video game violence in the risk factor paradigm, such as Boxer, Huesmann, Bushman, O'Brien and Moceri (2009), Braun, Stopfer, Müller, Beutel and Egloff (2016), DeLisi et al., (2013), Exelmans, Custers, and Van den Bulck (2015), Gentile and Bushman (2012) and Mariano (2016).

Considering the existence of this effect triggers a whole series of repercussions. If the nature of the game plays an important role in the probability of manifestation of different behaviors, the knowledge produced by this area can subsidize, on the one hand, as it draws attention of digital game developers to which characteristics may favor the training of different behaviors and lead to a new perspective for the development of serious games (for example, aiming to reduce antisocial behaviors). On the other hand, deepening knowledge on the effects of digital games on behavior has the potential to provide information to the governmental organizations responsible for regulating the content production sector (Funk, Pizzo, \& Baker, 2018).

Considering the relevance of this construct, the aim of the present study is to investigate the relationship between violent video games, dispositional traits and antisocial behaviors. The definition of personality used in this study was proposed by McAdams (2006), who conceives it as an individual variation represented by patterns of development, dispositional traits, characteristics of adaptation and self-definition of life, situated in culture and social context.

Next, we shall discuss the General Aggression Model, a widely used theoretical model in the study of this issue, as it is integrative and seeks to explain the processes that are involved in aggression, followed by 
evidence that supports or questions its assumptions (Arriaga, Monteiro \& Esteves, 2008).

\section{Description of the General Aggression Model}

The General Aggression Model (GAM) proposed by Anderson and Bushman (2002) is one of the most recent theoretical models about aggression and it is also the most widely used in research on violence in the media. It emphasizes three subtypes of structures: perceptual schemas, which are used to identify phenomena such as everyday physical objects (chairs) or social events (personal insults); personal schemas, which include beliefs about a particular person or group; and behavioral scripts, which contain information about how people behave under different circumstances. These structures, developed by the experience of individuals, are capable of influencing perceptions at different levels. They are processes that become more automatic as they are used and they are related to affective states and guide behavioral response to environmental demands (Anderson \& Bushman, 2002).

Three aspects are central to this model. The first one is related to several situational and individual factors and contextual characteristics present in a given situation (such as the characteristics of a given digital game) and how the environmental stimuli are interpreted by the individual. Among individual factors, Anderson and Bushman (2002) highlight personality traits, sex, beliefs, attitudes and values, all of which influence how individuals interpret ambiguous situations and manifest aggressive/violent behavior.

When analyzing the susceptibility to the effects of violent video games, Markey and Markey (2010), for example, found that certain personality traits, when analyzed together, can be important moderators of the relationship between exposure to violent video games and aggressive behaviors. As for the analysis of the Five Personality Factors model, the authors emphasize that a high rate of neuroticism and low levels of agreeableness and conscientiousness could be related to the manifestation of aggressive behaviors.

Secondly, information derived from primary inputs (personal and situational, such as sex and provocation in traffic) influences the individual's current internal state due to the cognitive, affective and arousal dimensions. And finally, information is interpreted by the individual, resulting in impulsive or controlled behaviors manifested by the individual; these behaviors are compatible with the nature of situational and individual factors (Anderson \& Bushman, 2002).
It has a cyclical character in the model because the outcomes of the decisive process are used as input for a later episode. In this sense, repeated exposure to specific digital games can be considered as a training situation, since, at each exposure, specific behavioral scripts and cognitive schemas are reinforced and the chances of these behaviors manifesting themselves in other situations is high (Anderson \& Bushman, 2002).

Studies were carried out with the purpose of directly or indirectly testing the relationships between the variables predicted in the GAM and violent video games, such as those by Arriaga, Monteiro and Esteves (2008) that address the potential effects of violent video games on aggression. Research conducted by Greitemeyer (2013), Hasan, Bègue and Bushman (2013) and Kim and Sundar (2013) also found an increase in aggressive behavior. This explains the use of the GAM in the present study. The hypothesis of the study is that violent video gaming predicts aggressive behavior.

\section{Method}

\section{Participants}

A total of 249 high school students from two public schools in the city of João Pessoa/PB, aged $13-20$ years $(\mathrm{M}=15.4, \mathrm{SD}=1.12)$, of which most were women $(62 \%)$, single $(98 \%)$ and in first year of high school (59\%), participated in the study. The study used convenience sampling (non-probabilistic).

\section{Instruments}

Scale of Violence in Video Games: the scale was developed for the present study; it is composed of three items that aim to quantify the violence of electronic games. It was used to obtain information about the nature and quality of the digital games played by the participants, and the questions were based on the Anderson and Dill (2000) study, as replicated in several countries (Anderson et al., 2017). Participants indicated the quantity of violence in their favorite video game on a scale of 1 (none) to 7 (a lot). The items in the instrument were as follows: "How much violent content is there in your favorite video game?" "How much death is there in your favorite video game?" and "How bloody is your favorite video game?". Correlations between these items ranged from 0.79 to 0.85 and Cronbach's alpha was 0.93 .

Buss-Perry Aggression Questionnaire. The 26-item questionnaire was proposed by Buss and Perry (1992) 
and it assesses four dimensions of aggression: physical aggression (e.g., If someone hits me, I hit back), verbal aggression (e.g., I cannot keep my mouth shut when people disagree with me), anger (e.g., Some friends say I'm hothead), and hostility (e.g., Sometimes jealousy eats me from the inside). These items are answered on a five-point scale $(1=$ totally disagree to $5=$ strongly agree). It was adapted for the Brazilian context by Gouveia, Chaves, Peregrino, Branco and Gonçalves (2008) who found the following coefficients of internal consistency: verbal aggression $(\alpha=.72)$, anger $(\alpha=.83)$, and physical aggression $(\alpha=.85)$ and hostility $(\alpha=.77)$.

Questionnaire on Antisocial Behaviors and Delinquency. A 20-item instrument equally distributed in two factors (antisocial and delinquency), which was adapted for the Brazilian context by Gouveia, Santos, Pimentel, Diniz and Fonseca (2009). Participants rate how often they have felt the behaviors described in each item, and their responses are rated on a scale ranging from $1=$ never to $10=$ always. Examples are as follows: antisocial factor item 'refusing to do the requested tasks (at work, at school or at home)' and the delinquency factor 'making money threatening weaker people'. Cronbach alpha revealed .84 for the antisocial behavior factor and .82 for the delinquent behavior factor (Gouveia, Santos, Pimentel, Diniz, \& Fonseca, 2009).

The Five-Factor Model of Personality - BFI-44 (Big Five Inventory). It was first developed by John, Donahue and Kentle (1991) in English, and validated in Brazil by Andrade (2008). The questionnaire consists of 34 items, which correspond to five factors, namely: Openness, Conscientiousness, Extroversion, Agreeableness and Neuroticism. In the validation process, the following alpha values were found: .65 to .75 ; Openness $(\alpha=.65)$, Neuroticism $(\alpha=.75)$, Extroversion $(\alpha=$ .75), Conscientiousness ( $\alpha=.65)$, and Agreeableness $(\alpha=.69)$. To respond, the participant indicated how much each attribute characterized him/her on a Likert scale with the following response options: $1=$ Strongly disagree $5=$ Strongly agree.

Sociodemographic Questionnaire. It was used to characterize the sample with items such as sex, age, marital status and level of education.

\section{Procedures}

The present study strictly followed the ethical principles recommended by the Ethics Committee under Resolution 466/2012, which deals with research and human testing (Report number: 1.310.836). To collect data at the school, previous contact was made with the school principals to obtain consent for the research. After confirming the availability of students for voluntary participation in the study, the term of free and informed consent (TFIC, filled out by the legal guardian of the participant when under the age of 18 years) and the term of free and clarified assent (TFCA, filled out by the participant when under the age of 18 years) were signed and the objectives related to the study were explained to the students and the confidentiality of the participants' answers was assured. During the data collection, participants answered the questionnaires individually, but collectively in a classroom with an average of 30 students per session. The average duration of the questionnaire administration was 30 minutes per classroom, considering all steps, and two psychology students administered the instrument. To reduce the impact on classroom activities, the questionnaire was administered at the end of the lesson when the teacher had already finished the daily class program. The questionnaire was administered at the end of the school day or close to the break time. The teacher remained in the room throughout the administration of the questionnaire, but without any intervention during the process. If the students or parents did not give consent to be in the study, the students were dismissed at the end of the class before the questionnaire was administered.

\section{Data analysis}

The research data were organized and statistically analyzed using the SPSS Statistics software, version 22.0 (IBM). Descriptive statistics were performed focusing on the exploratory analysis of the data. Pearson correlation analysis and comparison of means were used to verify possible associations among the variables of the study. After this step, the variables that revealed a relation with the dependent variables of the study (physical aggression and verbal aggression) were the object of simple and multiple regression analyses. In the present study, the factors of physical aggression and verbal aggression will be used as measures of the criterion variable (aggressive behavior), since they consist of the description of behaviors (and not of internal states), which are usually expressed in the opinion of the respondent. The order of magnitude of the correlation effect was based on Dancey and Reidy (2013), of which weak: $r=.10$ to .30 ; moderate: $r=.40$ to .6 ; strong: $r=.70$ to 1 . 


\section{Results}

First we sought to investigate how the variables $(\mathrm{VG}=$ Violence in Games, $\mathrm{AG}=$ Agreeableness, $\mathrm{OP}$ = Openness, $\mathrm{C}=$ Conscientiousness, $\mathrm{N}=$ Neuroticism, $\mathrm{E}=$ Extroversion, $\mathrm{AS}=$ Antisocial Behavior, $\mathrm{D}$ $=$ Delinquent Behavior, $\mathrm{PA}=$ Physical Aggression $; \mathrm{VA}$ = Verbal Aggression, $\mathrm{A}=$ Anger; $\mathrm{H}=$ Hostility) of the study were related. Table 1 shows the means and standard deviations of the variables and the correlation scores among them.

There was a positive correlation between exposure to violent games and physical aggression $(r=.23, p$ $<0.001)$, the only dimension of the Buss-Perry Aggression Questionnaire related to the Scale of Violence in Video Games. In the questionnaire on Antisocial Behavior and Delinquency, a weak correlation was found between Violence in Video Games and the Antisocial dimension $(r=.14, p=.03)$. For personality traits, there were two negative correlations between the factors Violence in Video Games and Conscientiousness $(r=-.13, p=.03)$ and Agreeableness $(r=-.17, p=.01)$.

The Conscientiousness factor also correlated negatively with Physical Aggression $(r=-.14, p=.03)$. On this latter factor, other significant associations were found, for example, with the trait of Neuroticism $(r=$ $.26, p<.01)$ and Antisocial Behavior $(r=.36, p<.01)$.
The Verbal Aggression dimension, in turn, correlated with the Agreeableness $(r=.13, p=.04)$ and Neuroti$\operatorname{cism}(r=.23, p<.01)$ factors in addition to the Physical Aggression dimension $(r=.31, p<.01)$. However, there was no statistically significant relationship between Verbal Aggression and exposure to violent games. Finally, when analyzing the variable sex, we observed a significant difference between men and women for Physical Aggression, $t(247)=2.09, p=.04, d=.27$, and Verbal Aggression, $t(247)=2.27, p=.02, d=.30$. Men $(\mathrm{M}=$ 2.10) presented higher rates of physical aggression than women $(\mathrm{M}=1.90)$, but women $(\mathrm{M}=3.14)$ presented higher rates of verbal aggression than men $(\mathrm{M}=2.80)$.

In accordance with the correlation findings, we sought to investigate the predictive power of the variables for the Physical Aggression dimension (Dependent Variable) using simple and multiple regression analyses. First the factor Violence in Video Games (Independent Variable), the main objective of the study, was included, followed by the constituent variables of the scales and the sex variable, established as the specific objectives.

When the Violence in Video Games factor (Model 1) was included, a predictive power was observed $(\beta=$ $.23, p<.01)$. However, this model explains only $5.2 \%$ of the variance in Physical Aggression.

In Model 2, the Agreeableness, Openness, Conscientiousness, Neuroticism, Extroversion, Antisocial

Table 1.

Means, standard deviations, and correlations of all study variables

\begin{tabular}{|c|c|c|c|c|c|c|c|c|c|c|c|c|c|c|c|}
\hline & & Mean & SD & 1 & 2 & 3 & 4 & 5 & 6 & 7 & 8 & 9 & 10 & 11 & 12 \\
\hline 1 & VG & 3.29 & 1.84 & & & & & & & & & & & & \\
\hline 2 & $A G$ & 4.37 & 0.69 & $-0.17^{* *}$ & & & & & & & & & & & \\
\hline 3 & OP & 3.75 & 0.62 & -0.09 & $0.29^{* *}$ & & & & & & & & & & \\
\hline 4 & C & 3.29 & 0.69 & $-0.13^{*}$ & $0.13^{*}$ & $0.15^{* *}$ & & & & & & & & & \\
\hline 5 & $\mathrm{~N}$ & 3.03 & 0.97 & -0.01 & 0.06 & $0.12^{*}$ & $-0.20^{* *}$ & & & & & & & & \\
\hline 6 & $\mathrm{E}$ & 3.13 & 0.85 & -0.00 & $0.21^{* *}$ & $0.18^{* *}$ & $0.21^{* *}$ & 0.07 & & & & & & & \\
\hline 7 & AS & 2.23 & 1.19 & $0.14^{*}$ & $-0.24^{* *}$ & -0.05 & $-0.22^{* *}$ & 0.06 & 0.01 & & & & & & \\
\hline 8 & $\mathrm{D}$ & 1.21 & 0.75 & 0.01 & $-0.27^{* *}$ & $-0.11^{*}$ & -0.02 & $-0.11^{*}$ & $-0.11^{*}$ & $0.55^{* *}$ & & & & & \\
\hline 9 & $\mathrm{PA}$ & 1.98 & 0.75 & $0.23^{* *}$ & -0.08 & 0.00 & $-0.14^{*}$ & $0.26^{* *}$ & -0.01 & $0.36^{* *}$ & $0.11^{*}$ & & & & \\
\hline 10 & VA & 3.01 & 1.17 & -0.03 & $0.13^{*}$ & $0.23^{* *}$ & 0.08 & $0.23^{* *}$ & 0.04 & 0.09 & -0.07 & $0.31^{* *}$ & & & \\
\hline 11 & A & 2.64 & 1.02 & -0.00 & $0.12^{*}$ & $0.16^{* *}$ & $-0.16^{* *}$ & $0.59^{* *}$ & $0.11^{*}$ & $0.18^{* *}$ & -0.06 & $0.54^{* *}$ & $0.45^{* *}$ & & \\
\hline 12 & $\mathrm{H}$ & 3.13 & 0.82 & 0.05 & -0.02 & $0.10^{*}$ & -0.08 & $0.26^{* *}$ & -0.05 & $0.14^{*}$ & -0.09 & $0.32^{* *}$ & $0.34^{* *}$ & $0.41^{* *}$ & \\
\hline
\end{tabular}

Note: $* \mathrm{p}<0.05$ and $* * \mathrm{p}<0.01 . \mathrm{VG}=$ Violence in Games; $\mathrm{AG}=$ Agreeableness; $\mathrm{OP}=$ Openness; $\mathrm{C}=$ Conscientiousness; $\mathrm{N}=\mathrm{Neuroticism}$; $\mathrm{E}=$ Extroversion; $\mathrm{AS}=$ Antisocial Behavior; $\mathrm{D}=$ Delinquent Behavior; $\mathrm{PA}=$ Physical Aggression; $\mathrm{VA}=$ Verbal Aggression, $\mathrm{A}=\mathrm{Anger} ; \mathrm{H}=$ Hostility. 
Table 2.

Simple and multiple regression (enter method) for predicting physical aggression

\begin{tabular}{|c|c|c|c|c|c|c|c|}
\hline & $\mathrm{R}$ & $\mathrm{R}^{2}$ & $\mathrm{~F}$ & $\operatorname{Sig}(F)$ & Beta & $\mathrm{t}$ & $\mathrm{P}$ \\
\hline $\mathrm{VG}$ & 0.227 & 0.052 & 13.428 & 0.001 & 0.227 & 3.664 & 0.001 \\
\hline VG + & 0.649 & 0.42 & 15.628 & 0.001 & 0.187 & 3.651 & .000 \\
\hline $\mathrm{AM}+$ & & & & & -0.045 & -.808 & .420 \\
\hline $\mathrm{AB}+$ & & & & & -0.049 & -.910 & .364 \\
\hline$C+$ & & & & & 0.025 & .460 & .646 \\
\hline $\mathrm{N}+$ & & & & & -.062 & -.994 & .321 \\
\hline $\mathrm{E}+$ & & & & & -.054 & -1.011 & .313 \\
\hline AS + & & & & & .222 & 3.378 & .001 \\
\hline $\mathrm{D}+$ & & & & & .003 & .055 & .957 \\
\hline $\mathrm{AV}+$ & & & & & .086 & 1.474 & .142 \\
\hline $\mathrm{R}+$ & & & & & .490 & 6.894 & .000 \\
\hline $\mathrm{H}$ & & & & & .069 & 1.220 & .224 \\
\hline VG + & 0.666 & 0.443 & 14.378 & 0.001 & .144 & 2.755 & .006 \\
\hline $\mathrm{AM}+$ & & & & & -.008 & -.144 & .886 \\
\hline $\mathrm{AB}+$ & & & & & -.036 & -.682 & .496 \\
\hline$C+$ & & & & & .012 & .219 & .827 \\
\hline $\mathrm{N}+$ & & & & & -.047 & -.755 & .451 \\
\hline $\mathrm{E}+$ & & & & & -.067 & -1.261 & .208 \\
\hline AS + & & & & & .182 & 2.756 & .006 \\
\hline $\mathrm{D}+$ & & & & & .003 & .043 & .966 \\
\hline $\mathrm{AV}+$ & & & & & .090 & 1.567 & .118 \\
\hline $\mathrm{R}+$ & & & & & .512 & 7.262 & .000 \\
\hline $\mathrm{H}+$ & & & & & .091 & 1.617 & .107 \\
\hline $\mathrm{I}+$ & & & & & -.043 & -.845 & .399 \\
\hline $\mathrm{S}$ & & & & & -.179 & -3.075 & .002 \\
\hline
\end{tabular}

Note: PA: Physical Aggression; Violence in Games = VG; Agreeableness = AG; Openness = OP; Conscientiousness = C; Neuroticism = N; Extroversion = E; Antisocial = AS; Delinquency = D; Verbal Aggression = VA, Anger = A; Hostility = H; Sex = S; Age = I.

Behavior, Delinquent Behavior, Verbal Aggression, Anger and Hostility factors were included. Therefore, controlling these variables, we found that violence in video games still predicts physical aggression $(\beta=.19$, $p<.01)$. On the other hand, we found that anger and antisocial behavior had better predictive power $(\beta=$ $.49, p<.01$ and $\beta=.22, p<.01$, respectively). As shown in Table 2, Model 2 accounts for $42 \%$ of the variance explanation, versus $5.2 \%$ for the first model.

Finally, Model 3 included sex and age as independent variables. The sex variable presented a predictive power of $\beta=-.17, p<.01$. This model explains $44.3 \%$ of the variance with violent video gaming and it predicts physical aggression, $\beta=.14, p<.01$. However, anger $(\beta=.51, p<.01)$, antisocial behavior $(\beta=.18, p$ $<.01)$ and sex were the best predictors.

\section{Discussion}

The aim of the present study was to investigate the relationship between violent video gaming, dispositional traits and antisocial behavior. Evidence suggests that exposure to violent games may explain the manifestation of antisocial behaviors, particularly 
those related to physical aggression. Moreover, evidence suggests that a set of variables, such as those related to personality, sex, and specific affective states, have considerable explanatory power, and studies that seek to understand these interactions may be promising avenues for further research.

The scientific literature indicates a positive relationship between youth exposure to violent games and aggression, which corroborates the data found in the present study and studies discussed below. Among these studies, the meta-analysis of Greitemeyer and Mügge (2014) revealed an increase in variables related to aggression. In the study by Gentile, Swing, Anderson, Rinker, and Thomas (2016), usual players of violent games demonstrated desensitization to aggression.

The data found by Hasan et al., (2013) showed that violent video game players presented higher levels of aggression. Kim and Sundar (2013) have identified increased aggressiveness in players who have used weapon-shaped controllers. Finally, in the study by Saleem, Anderson and Gentile (2012), children playing violent video games presented more offensive behaviors and less prosocial behaviors. In the present study, the preference for violent digital games can be a predictor of physical aggression even if the effect of several variables such as personality traits, anger, antisocial behavior or sex are controlled.

The regression analyses revealed a predictive power of experience with violent digital games regarding physical aggression. These findings support the GAM prediction that violent media content influences the manifestation of aggressive behavior. In this sense, playing violent video games would increase the expectation that aggressive situations should be treated aggressively, leading to increased aggressiveness (Anderson \& Bushman, 2002). Anger, as a predictor of aggressive behavior, would be a facilitator of aggressiveness as it was the best predictor of physical aggression in the present study. In addition, studies point to increased aggressiveness due to cathartic reactions and increase in the likelihood of a new aggressive behavior, which is different from the cathartic hypothesis that reaction causes a decrease in aggressiveness. These findings corroborate the GAM integrative hypothesis on human aggression and its cyclic triggering (Bushman, Baumeister, \& Stack, 1999; Tedeschi \& Felson, 1994).

The correlation between exposure to violent games and antisocial behavior discussed in the results has also been the object of studies on delinquency and electronic gaming. Using the Risk Factor Paradigm, exposure to violent games is a risk factor for delinquent behavior (Boxer et al., 2009; DeLisi et al., 2013, Exelmans, Custers, \& Van den Bulck, 2015; Gentile \& Bushman, 2012). Within this perspective, violent games would be another factor among many others that comprise the problem of aggression and delinquent behavior. The second most important factor to explain physical aggression was antisocial behavior, which was expected, since aggression can be understood as another antisocial behavior (Pimentel, 2004).

An alternative interpretation for the data found may suggest, in agreement with several criticisms to the GAM model, that exposure to violent games, although taking place in the explanatory model of physical aggression, may be overvalued to the detriment of other variables with greater predictive power (Elson \& Ferguson, 2013). Therefore, the preference for violent digital games could just be another consequence, for example, of more stable dispositional traits and related to antisocial behaviors. In addition, participants with a high level of Neuroticism and low levels of Agreeableness and Conscientiousness, for example, might be more susceptible to the effect of game content on their behavior (Markey \& Markey, 2010), leading to a more dispositional interpretation of the effects of media on behavior.

However, as GAM assumes relevant variables of input, individual characteristics (Anderson \& Bushman, 2002) as well as a set of evidence favorable to an interaction relationship between these variables for understanding the relationship between violent game playing and antisocial behavior. The results found with the participants of this study indicated a negative correlation between violent games and Conscientiousness and Agreeableness traits, confirmed by the results found by Anderson et al., (2004). On the other hand, Chory and Goodboy (2011) found no correlation between Conscientiousness and violent video game playing but corroborated the negative correlation with Agreeableness. Thus, further in-depth research must be conducted, since new empirical evidence, particularly focusing on testing these relationships, can promote positive discussions on the subject.

With regard to sex, this variable was also considered one of the risk factors associated with violent games and aggressive and antisocial behaviors, as suggested in the findings of the present study. Therefore, these findings corroborate the literature 
that boys are more attracted to violent games (Lemmens, Valkenburg, \& Peter, 2011; Vandercammen \& Vandenbrande, 2011).

However, this study is not without limitations. Among them, three deserve attention. First, the results are based on self-reporting measures that may lead to bias in responses due to social desirability. Second, there may be other important risk factors to better detail the problem that were not included in the research. Finally, the cross-sectional study precludes inference of causality. The results are restricted to the study sample.

Despite the limitations, the study can help to explain the problem involving violent games and aggression by raising questions about possible predictive factors. On the other hand, although the significance of video game violence has been proven to understand physical aggression, the role of anger and antisocial behavior, as well as sex, should be emphasized. These variables proved to be better predictors of aggressive behavior. Therefore, further studies should include these variables in an experimental design to investigate the possible effect of violent games on the behavior of players of different age groups. For example, the difference between the time of exposure to games, which was not considered in this research, and use of specific types of games could be investigated.

Finally, the predictive power of video game violence in aggressive behavior, after controlling for several variables, such as personality traits, was confirmed (Barlett \& Anderson, 2012; Tang \& Fox, 2016). The present study contributes to those that have investigated the role of violent media in aggressive and antisocial behaviors (Braun, Stopfer, Müller, Beutel, \& Egloff, 2016; DeLisi et al., 2013), promoting the development in the field in Brazil.

\section{References}

Anderson, C. A., \& Bushman, B. J. (2001). Effects of violent video games on aggressive behavior, aggressive cognition, aggressive affect, physiological arousal, and prosocial behavior: A meta-analytic review of the scientific literature. Psychological science, 12(5), 353-359.

Anderson, C. A., \& Bushman, B. J. (2002). Human aggression. Annual Review of Psychology, 53(1), 27-51.

Anderson, C. A., \& Dill, K. E. (2000). Video Games and Aggressive Thoughts, Feelings, and Behavior in the Laboratory and in Life. Journal of Personality and Social Psychology, 78(4), 772-790.

Anderson, C. A., Carnagey, N. L., Flanagan, M., Benjamin, A. J., Eubanks, J., \& Valentine, J. C. (2004). Violent video games: Specific effects of violent content on aggressive thoughts and behavior. $A d$ vances in Experimental Social Psychology, 36, 199-249.

Anderson, C. A., Shibuya, A., Ihori, N., Swing, E. L., Bushman, B. J., Sakamoto, A., \& Saleem, M. (2010). Violent video game effects on aggression, empathy, and pro social behavior in eastern and western countries: A meta-analytic review. Psychological Bulletin, 136, 151- 173.

Anderson, C. A., Suzuki, K., Swing, E. L., Groves, C. L., Gentile, D. A., Prot, S., ... Petrescu, P. (2017). Media Violence and Other Aggression Risk Factors in Seven Nations. Personality and Social Psychology Bulletin, 43(7), 986-998.

Andrade, J. M. (2008). Evidências do Inventário dos Cinco Grandes Fatores de Personalidade para o Brasil. Tese de doutorado não-publicada. Departamento de Psicologia, Universidade de Brasília, Brasília, DF.

Arriaga, P., Monteiro, M. B., \& Esteves, F. (2008). Factores mediadores e moderadores dos efeitos dos jogos electrónicos violentos na agressão interpessoal. Revista Portuguesa de Pedagogia, 203-223.

Ashinoff, B. K. (2014). The potential of video games as a pedagogical tool. Frontiers in Psychology, 5, 1109. doi:10.3389/fpsyg.2014.01109

Barlett, C. P., \& Anderson, C. A. (2012). Direct and indirect relations between the Big 5 personality traits and aggressive behavior. Personality \& Individual Differences, 52, 870-875.

Boxer, P., Huesmann, L. R., Bushman, B. J., O’Brien, M., \& Moceri, D. (2009). The role of violent media preference in cumulative developmental risk for violence and general aggression. Journal of youth and adolescence, 38(3), 417-428.

Braun, B., Stopfer, J. M., Müller, K. W., Beutel, M. E., \& Egloff, B. (2016). Personality and video gaming: Comparing regular gamers, non-gamers, and gaming addicts and differentiating between game genres. Computers in Human Behavior, 55, 406-412.

Bushman, B. J., \& Huesmann, L. R. (2006). Shortterm and long-term effects of violent media on 
aggression in children and adults. Archives of Pediatrics and Adolescent Medicine, 160, 348-352.

Bushman, B. J., \& Huesmann, L. R. (2014). Twenty-Five Years of Research on Violence in Digital Games and Aggression Revisited. European Psychologist, 19(1), 47-55.

Bushman, B., Baumeister, R., \& Stack, A. (1999). Catharsis, aggression, and persuasive influence: Self-fulfilling or self-defeating prophecies? Journal of Personality and Social Psychology, 76(3), 367-376.

Buss, A. H., \& Perry, M. (1992). The aggression questionnaire. Journal of Personality and Social Psychology, 63(3), 452-459.

Chory, R. M., \& Goodboy, A. K. (2011). Is basic personality related to violent and non-violent video game play and preferences? Cyberpsychology, Behavior, and Social Networking, 14(4), 191-198.

Dancey, C. P., \& Reidy, J. (2013). Estatística sem matemática para psicologia. Penso Editora.

DeLisi, M., Vaughn, M. G., Gentile, D. A., Anderson, C. A., \& Shook, J. J. (2013). Violent video games, delinquency, and youth violence: New evidence. Youth Violence and Jwvenile Justice, 11(2), 132-142.

Elson, M., \& Ferguson, C. J. (2013). Twenty-Five Years of Research on Violence in Digital Games and Aggression. European Psychologist, 19(1), 33-46.

Elson, M., Mohseni, M. R., Breuer, J., Scharkow, M., \& Quandt, T. (2014). Press CRTT to measure aggressive behavior: The unstandardized use of the competitive reaction time task in aggression research. Psychological Assessment, 26(2), 419-32.

Exelmans, L., Custers, K., \& Van den Bulck, J. (2015). Violent video games and delinquent behavior in adolescents: a risk factor perspective. Aggressive Behavior, 41(3), 267-279.

Farrington, D. P. (2000). Explaining and preventing crime: The globalization of knowledge - The American Society of Criminology 1999 presidential address. Criminology, 38(1), 1-24.

Ferreira, P. A., Carneiro, M. P., Miguéis, M. L., Soares, S., \& Esteves, F. (2009). Jogos de computador violentos e seus efeitos na hostilidade, ansiedade e activação fisiológica. Revista Lusófona de Ciências da Mente e do Comportamento, 1(1), 193-209.
Funk, D., Pizzo, A., \& Baker, B. (2018). eSport management: Embracing eSport education and research opportunities. Sport Management Review, 21(1), 7-13.

Gee, J. P. (2003). What video games have to teach us about learning and literacy. Computers in Entertainment, 1(1), 20-20.

Gentile, D. A., \& Bushman, B. J. (2012). Reassessing media violence effects using a risk and resilience approach to understanding aggression. Psychology of Popular Media Culture, 1(3), 138-151.

Gentile, D. A., Swing, E. L., Anderson, C. A., Rinker, D., \& Thomas, K. M. (2016). Differential neural recruitment during violent video game play in violent and nonviolent game players. Psychology of Popular Media Culture, 5(1), 39-51.

Gouveia, V. V., Chaves, C. M. C. M., Peregrino, R. R., Branco, A. O. C., \& Gonçalves, M. P. (2008). Medindo a agressão: o Questionário de Buss-Perry. Arquivos Brasileiros de Psicologia, 60(3), 92-103.

Gouveia, V. V., Mariano, T. E., Nascimento, A. M., Grangeiro, A. S. M., \& Medeiros, E. D. (2017). Escala de motivações para jogos online: estudo de adaptação à realidade brasileira. Temas em Psicologia, 25(1), 131-141.

Gouveia, V.V., Santos, W.S., Pimentel, C.E., Diniz, P.K.C., \& Fonseca, P.N. (2009). Questionário de comportamentos antissociais e delitivos: Evidências psicométricas de uma versão reduzida. Psicologia: Reflexão \& Crítica, 22(1), 20-28.

Granic, I., Lobel, A., \& Engels, R. C. M. E. (2014). The benefits of playing video games. American Psychologist, 69(1), 66-78. http://dx.doi.org/10.1037/ a0034857

Greitemeyer, T. (2013). Playing violent video games increases intergroup bias. Personality and Social Psychology Bulletin, 40(1), 70-78.

Greitemeyer, T., \& Mügge, D. (2014). Video games do affect social outcomes: A meta-analytic review of the effects of violent and prosocial video dame. Personality and Social Psychology Bulletin, 40, 578-589. doi:10.1177/0146167213520459

Hasan, Y., Bègue, L., \& Bushman, B. J. (2013). Violent video games stress people out and make them more aggressive. Aggressive Behavior, 39(1), 64-70. 
John, O. P., Donahue, E. M., \& Kentle, R. L. (1991). The Big Five Inventory-Versions $4 a$ and 54. Berkeley: University of California, Institute of Personality and Social Research.

Kasumovic, M., Blake, K., Dixson, B., \& Denson, T. (2015). Why do people play violent video games? Demographic, status-related, and mating-related correlates in men and women. Personality and Individual Differences, 86, 204-211. doi:10.1016/j. paid.2015.06.018

Kim, K. J., \& Sundar, S. S. (2013). Can interface features affect aggression resulting from violent video game play? An examination of realistic controller and large screen size. Cyberpsychology, Behavior, and Social Networking, 16(5), 329-334.

Krahé, B. (2014). Restoring the Spirit of Fair Play in the Debate About Violent Video Games. European Psychologist, 19(1), 56-59.

Kühn, S., Gleich, T., Lorenz, R. C., Lindenberger, U., \& Gallinat, J. (2014). Playing Super Mario induces structural brain plasticity: Gray matter changes resulting from training with a commercial video game. Molecular Psychiatry, 19(2), 265-271.

Lemmens, J. S., Valkenburg, P. M., \& Peter, J. (2011). The effects of pathological gaming on aggressive behavior. Journal of Youth and Adolescence, 40(1), 38-47.

Mariano, T. E. (2016). O impacto dos videogames nas cognições pró e antissociais. Dissertação de Mestrado. Departamento de Psicologia, Universidade Federal da Paraíba, João Pessoa.

Markey, P. M., \& Markey, C. N. (2010). Vulnerability to violent video games: A review and integration of personality research. Review of General Psychology, 14(2), 82-91.

Mora-Cantallops, M, \& Sicilia, M. A. (2018). MOBA games: A literature review. Entertainment Computing, 26, 128-138.

Pimentel, C. E. (2004). Valores humanos, preferência musical, identificaşão grupal e comportamentos antissociais. Dissertação de Mestrado não-publicada, Departamento de Psicologia, Universidade Federal da Paraíba, João Pessoa, PB.

Pinto, N. G. M., Coronel, D. A., \& Bresolin, R. P. (2013). Análise Comparativa da Evolução das Vendas e do PIB Per Capita dos Principais Mercados da Sétima Geração de Consoles de Videogames no Período de 2006-2011. REUNIR-Revista de Administração, Contabilidade e Sustentabilidade, 3(3), 44-60.

Retondar, M. J., \& Harris, E. R. A. (2013). Jogos eletrônicos e violência. Motrivivência, 25(40), 183-191.

Saleem, M., Anderson, C. A., \& Gentile, D. A. (2012). Effects of prosocial, neutral, and violent video games on college students' affect. Aggressive Behavior, 38(4), 263-271.

Stansbury, J. A., Wheeler, E. A., \& Buckingham, J. T. (2014). Can Wii engage college-level learners? Use of commercial off-the-shelf gaming in an introductory statistics course. Computers in the Schools, 31(1-2), 103-115.

Swing, E. L., Gentile, D. A., \& Anderson, C. A. (2009). Learning processes and violent video games. In R. E. Ferdig (Ed.), Handbook of Research on Effective Electronic Gaming in Education (Vol. II, pp. 876-892). New York: Information Science Reference.

Tang, W. Y., \& Fox, J. (2016). Men's harassment behavior in online video games: Personality traits and game factors. Aggressive behavior, 42(6), 513-521.

Tedeschi, J. T., \& Felson, R. B. (1994). Violence, aggression, \& coercive actions. Washington, DC: American Psychological Association.

Vandercammen, M., \& Vandenbrande, K. (2011). Jongeren en media. Brussel: Onderzoeks- en Informatiecentrum van de Verbruikersorganisaties.

Ybarra, M. L., Huesmann, L. R., Korchmaros, J. D., \& Reisner, S. L. (2014). Cross-sectional associations between violent video and computer game playing and weapon carrying in a national cohort of children. Aggressive Behavior, 40(4), 345-358.

Recebido em: 26/06/2018 Reformulado em: 12/03/2019 
About the authors:

Bruno Gonçalves de Medeiros - Professor at the Universidade Potiguar. Graduated in Psychology at the Universidade Federal da Paraíba. Specialization in Neuropsychology from the Universidade Cândido Mendes. Residency in Basic Attention at the Multicampi School of Medical Sciences of Universidade Federal do Rio Grande do Norte. Master in Collective Health at the Faculdade de Ciências da Saúde do Trairi/Universidade Federal do Rio Grande do Norte.

ORCID: https://orcid.org/0000-0003-0555-2122

E-mail: brunogonk@hotmail.com

Carlos Eduardo Pimentel - Adjunct Professor at the Department of Psychology of the Universidade Federal da Paraíba and at the Graduate Program in Social Psychology in the same institution. PhD in Social, Work, and Organizational Psychology from Universidade de Brasília. Incluir: CNPq Research Productivity Scholarship.

ORCID: https://orcid.org/0000-0003-3894-5790

E-mail: carlosepimentel@bol.com.br

Maurício Miranda Sarmet - Professor at the Instituto Federal de Educação, Ciência e Tecnologia da Paraíba. Psychologist, holds a Masters in Psychology and a PhD in Social, Work and Organizational Psychology from Universidade de Brasília. His main areas of research interest are: impact of videogames on human behavior, hu-man-artefact interaction and use of new technologies in correlational and experimental re-search.

ORCID: https://orcid.org/0000-0001-7342-2712

E-mail: mauricio.sarmet@ifpb.edu.br

Tailson Evangelista Mariano - PhD and Master in Social Psychology from the Universidade Federal da Paraíba. Psychologist graduated from Universidade Federal do Piauí. Member of the Media Psychology Laboratory (LPM) coordinated by Professor Dr. Carlos Eduardo Pimentel. Some research interests are: cognitive and social effects of virtual games, human values, psychometrics, and psychological evaluation.

ORCID: https://orcid.org/0000-0001-6716-0250

E-mail: tailsonmariano@hotmail.com

Contact:

Carlos Eduardo Pimentel

Media Psychology Lab, Universidade Federal da Paraíba, Centro de Ciências Humanas Letras e Artes - Campus I, Departamento de Psicologia, Cidade Universitária, s/n, Cidade Universitária

João Pessoa-PB, Brasil

CEP: $58051-900$

Psico-USF, Bragança Paulista, v. 25, n. 2, p. 261-271, abr./jun. 2020 
